\title{
Occurrence Pattern and Behavior of the Japanese MittenCrab Eriocheir japonicus DE HAAN in the Marine Environment
}

\author{
SATOSHI KOBAYASHI and SHUHEI MATSUURA
}

Department of Fisheries, Faculty of Agriculture, Kyushu University

\begin{abstract}
KOBAYASHI, SAToshi and Shuhei MATSUURA (Department of Fisheries, Faculty of Agriculture, Kyushu University). 1994. Occurrence Pattern and Behavior of the Japanese Mitten Crab Eriocheir japonicus DE HAAN in the Marine Environment. Benthos Research, 46: 49-58.

The habitat, period of occurrence and behavior of Eriocheir japonicus in the sea was described. E. japonicus was collected from various types of sea bottom. The period when $E$. japonicus appeared in the sea (early September to early July) overlapped with that of small-size brachyurans but for a shorter period with larger migratory brachyurans. $E$. japonicus was observed not to dig burrows, but to bury itself in the sand or hide under rocks. Many males were collected while wandering, whereas many females were collected while hiding under rocks. Attached organisms (mainly green algae) on the exoskeleton were found more frequently on males than on females, suggesting that males are more active on the bottom than females.
\end{abstract}

\section{Introduction}

The Japanese mitten crab Eriocheir japonicus is catadromous, migrating downstream into the marine environment (including brackish water) to mate and spawn (MoRITA, 1974; Kobay ASHI \& MATSUURA, 1991). Their behavior in the sea has not been reported in detail, in contrast to some other intertidal and sublittoral brachyuran species (WADA, 1976; NAKASONE, 1977; KIKUCHI et al., 1981; T AKAHASHI et al., 1985). NAKASONE (1977) classified 47 decapod crusta-

Received June 4, 1993: Accepted December 17, 1993 ceans inhabiting an estuary into 5 groups according to their modes of life (i.e., always living in burrows; living under stones and in crevices of river bank if these are present, but otherwise making burrows; living only under stones or among stones and pebbles; crawling about freely on substrata; swimming about at the water's edge or in shallow pools around stones in the intertidal area) and described the distribution of each species in relation to the type of sediment along the sea bottom and the tidal level.

Being a large intertidal brachyura $(35-85 \mathrm{~mm}$ carapace width in the brackish water area) (Kobayashi \& MatsUURA, 1991), E. japonicus is 
deemed to play a significant role within the intertidal and sublittoral communities during their breeding season. Therefore, information on their behavior in this microhabitat may be useful for understanding not only the characteristics of the species, but also its ecological niche, i.e. its interspecific relationships regarding food and habitat utilization.

The present paper describes the behavior of E. japonicus, in addition to the habitat and period of occurrence of brachyuran species, including E. japonicus, in a sea area. The position of $E$. japonicus within the intertidal and sublittoral brachyuran community is also discussed.

\section{Materials and Methods}

Sampling was carried out in the intertidal and shallow sublittoral zone (about $20,000 \mathrm{~m}^{2}$ ) at Tsuyazaki Beach $\left(33^{\circ} 47^{\prime} \mathrm{N}, 130^{\circ} 28^{\prime} \mathrm{E}\right)$, Munakata Country, Fukuoka Prefecture, Japan (Fig.1) at least once every few days between August 1990 and July 1991. The sampler wore waders and wandered up and down the beach for about $1 \mathrm{~h}$ during the ebb tide in the daytime; collection of E. japonicus was carried out using wire and hand-held nets, and the environmental

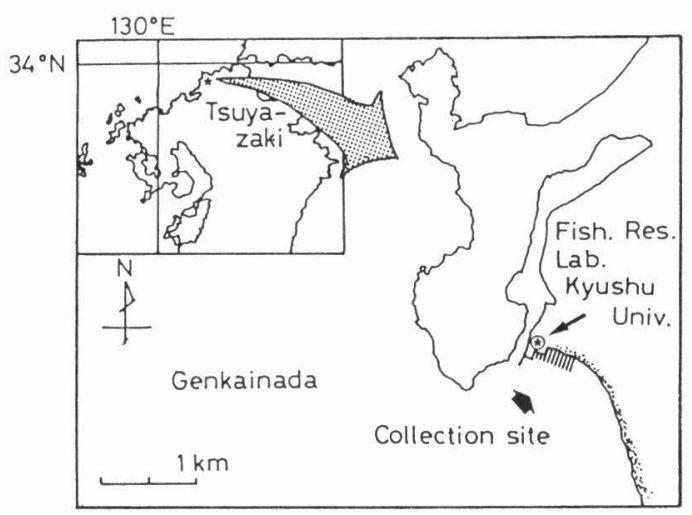

Fig. 1 Map of collection site. conditions of their habitat were recorded qualitatively. Depth of the areas surveyed was less than $1.2 \mathrm{~m}$. Other brachyuran crabs were also collected and their habitat was recorded. The water temperature at noon $\pm 2 \mathrm{~h}$ was recorded.The collected crabs were identified to species, and the maximum carapace width was measured for each crab. As for E. japonicus, the sex of each individual was determined and attached organisms on the exoskeleton were noted. The condition of the surface of the exoskeleton (carapace and walking legs) was classified into 4 classes (Fig.2): Class 0 for a clear

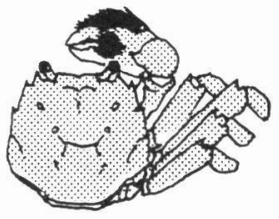

Class 0

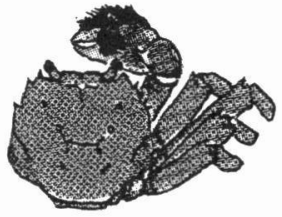

Class 1

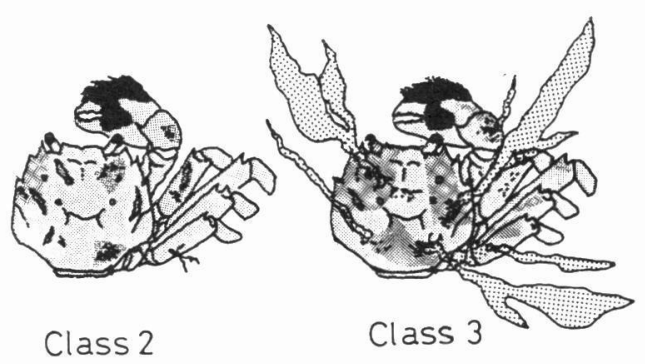

Fig.2 Appearance of the exoskeleton of $E$. japonicus classified into 4 classes: class 0 , a clear surface without attached organisms; class 1, a dirty surface without attached organisms; class 2, a small amount of attached organisms (lengths of the attached algae all $<10 \mathrm{~mm}$ ); class 3 , a large amount of attached organisms (lengths of the largest attached algae $\geqq$ $10 \mathrm{~mm})$. 
surface without attached organisms, class 1 for a dirty black surface without attached organisms, class 2 for a small amount of attached organisms (lengths of the attached algae $<10 \mathrm{~mm}$ ), and class 3 for a large amount of attached organisms (lengths of the largest attached algae $\geqq 10 \mathrm{~mm})$.

\section{Results}

\section{Environmental conditions}

A map indicating the distribution of bottom sediment in the collection site is shown in Fig.3. E. japonicus was collected from all bottom types of the study area: an artificial rocky shore (concrete cliff and piles of large rocks more than $1 \mathrm{~m}$ in length) (bottom type A), a sandy shore with numerous stones (less than $20 \mathrm{~cm}$ ) and rocks (not less than $20 \mathrm{~cm}$ ) (bottom type B), and a sandy shore with few stones (bottom type C). The medium diameter of the sand grains was $0.25 \mathrm{~mm}$. The environmental conditions were comparatively unstable, because stormy waves often moved the sand and buried the rocks. Furthermore, sometimes in the spring, a large amount of green algae (mostly Ulva pertusa) washed up on the shore covered a large part of the intertidal zone and trapped the crabs. The monthly mean water temperatures for each month ranged between $10.0^{\circ} \mathrm{C}$ (February) and $27.0^{\circ} \mathrm{C}$ (August) (see Fig.4).

\section{Habitat and occurrence period of brachyuran species}

The 16 brachyuran species collected are indicated in Table 1, and their collecting site and pe-

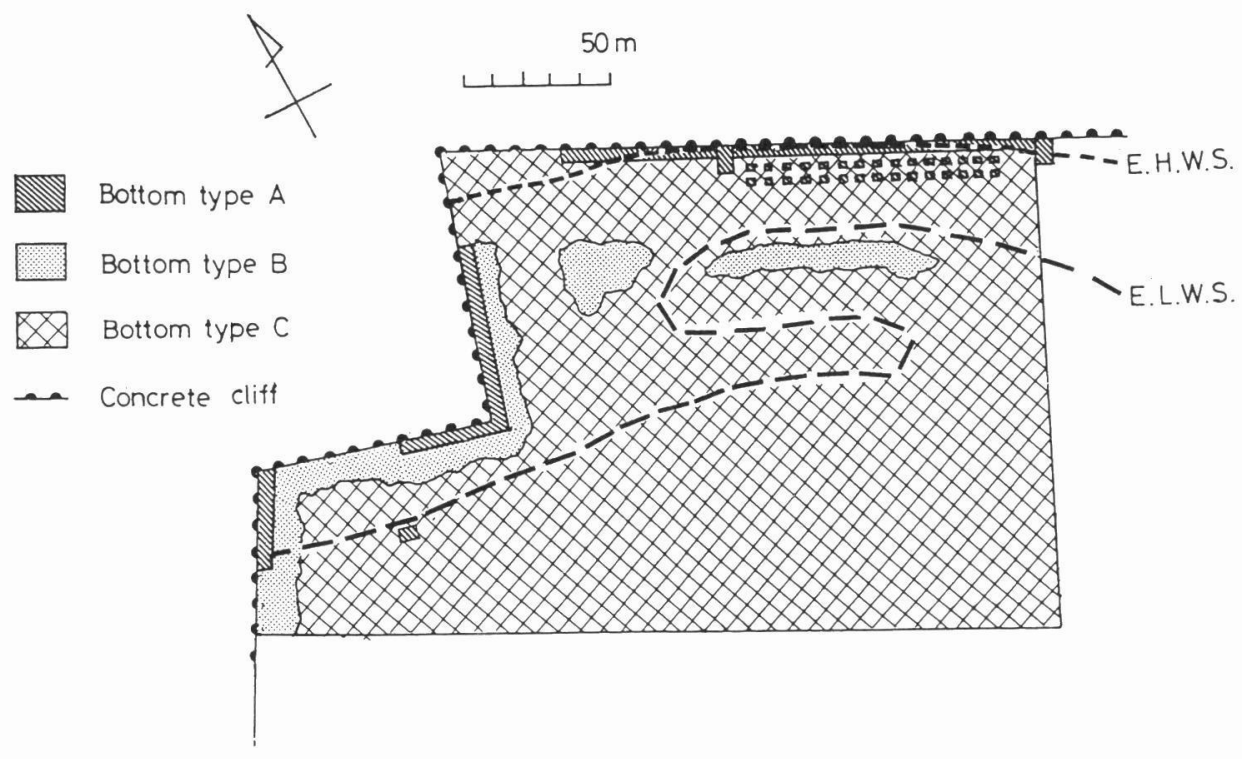

Fig.3 Map showing distribution of the type of bottom sediment at the collection site. Bottom type A: concrete and rocks of $\geqq 1 \mathrm{~m}$ in breadth; Bottom type B: sand with numerous stones and rocks; Bottom type C: sand with few stones; E.H.W.S.: extreme high water of spring tide; E.L.W.S.: extreme low water of spring tide. 


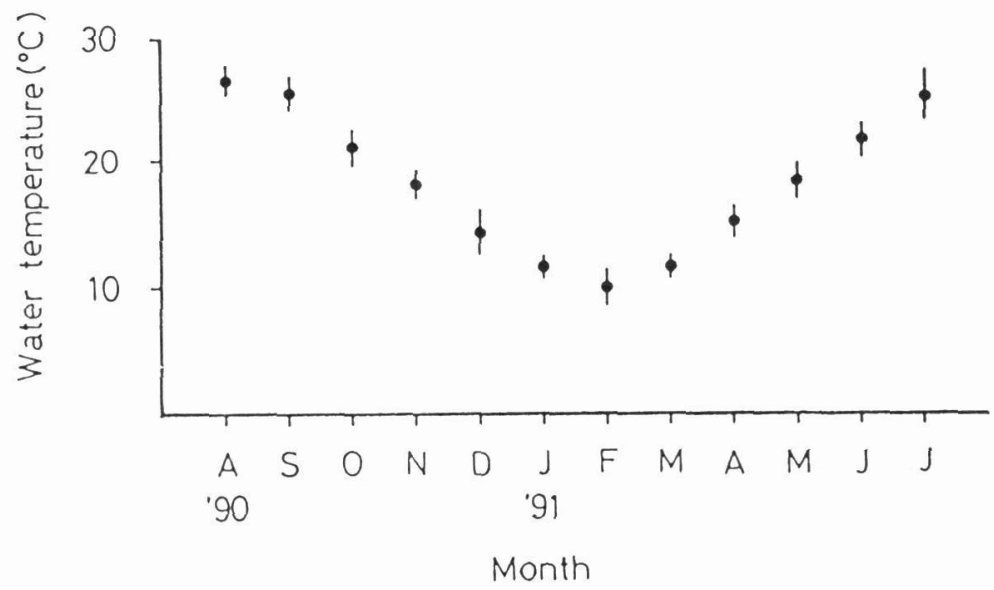

Fig.4 Monthly changes in water temperature at the study site. Dots and bars indicate mean and SD, respectively.

riod are indicated in Fig.5. Both E. japonicus (1) and C. japonica (12) were collected from all 3 types of bottom. Three grapsids (2-4), 2 xanthids ( $9 \& 10)$, and 2 majids ( $15 \& 16)$ were collected in both types $\mathrm{A}$ and B. One portunid (12), 1 calappid (14) and 2 ocypodids ( $7 \& 8$ ) were collected only in type C. Two grapsids ( 5 \& 6) and 1 pinnotherid (11) were collected only in type A. E. japonicus shared common places with other species collected. E. japonicus was collected on the rocks under the water in types $\mathrm{A}$ and $\mathrm{B}$ (in common with $2,3,12,15,16$ ), under the rocks in type B (in common with $2-4,12$ ), and within the sand above and under the water (burial in the sand) and on the sand under the water in type C (in common with 12-14). As for the occurrence period, smaller crabs were collected year round (maximum carapace width less than 40mm) from bottom types $\mathrm{A}$ and $\mathrm{B}$, but comparatively large species (maximum carapace width larger than $40 \mathrm{~mm}$ ) were collected only in limited periods. E. japonicus were collected from early September to early July (early autumn to early summer). C. japonica (12), $P$. pelagicus (13) and $M$. lunaris (14) were collected from early summer till mid-autumn. Thus, although E. japonicus had a wide range of habitats in common with many other species (especially C. japonica), it had only a short overlapping period with the other species.

\section{Behavior of $E$. japonicus}

E. japonicus did not dig burrows with a steady structure, but buried itself in the sand or hid under rocks (Fig.6). The crabs began to bury themselves in the sand from the posterior end, and in some cases they hid the whole body except for the part around their eye stalks and antennae. Burial took about 15 seconds (average from 8 cases). E. japonicus were active only when they were under the water. They wandered along the sand or over rocks, or else were found eating attached organisms or detritus on the rocks. However, when they were left in a tidepool or on land at low tide, they hid themselves in the sand or under the rocks and hardly moved. Figure 7 shows the posturing conditions of crabs at collection. These conditions were classified into 4 groups: wandering along the sand, staying on the rocks, hiding under the 


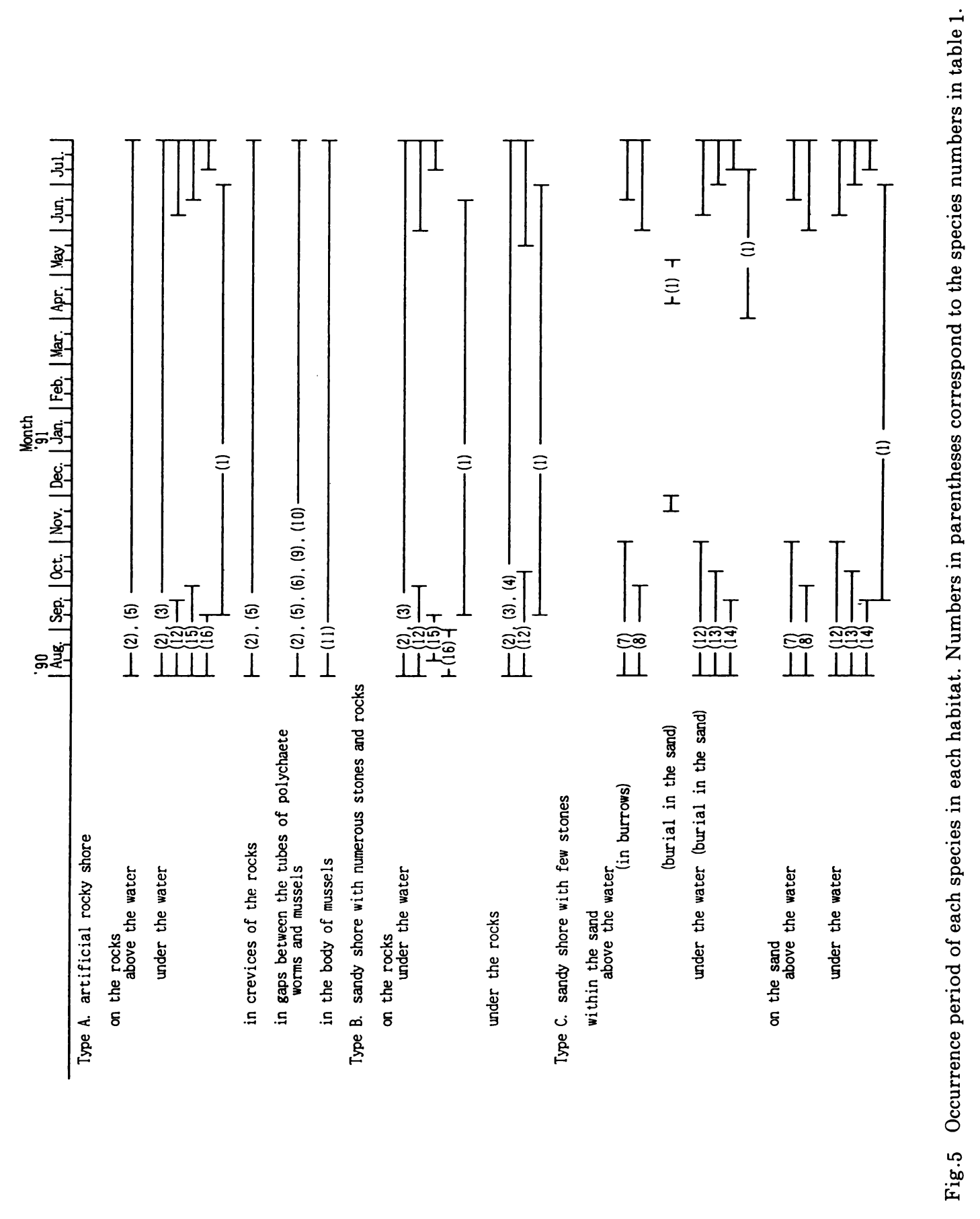


Table 1 Brachyuran species gathered at the collection site.

\begin{tabular}{|c|c|c|c|c|}
\hline No. & & Family \& Species & $\begin{array}{l}\text { Carapace } \\
\text { width }(\mathrm{mm})\end{array}$ & Abundance ${ }^{*}$ \\
\hline 1 & Grapsidae & Eriocheir japonicus DE HAAN & $35-75$ & c \\
\hline 2 & & Hemigrapsus sanguineus (DE HAAN) & $3-38$ & $\mathrm{~d}$ \\
\hline 3 & & Hemigrapsus penicillatus (DE HAAN) & $3-32$ & $c$ \\
\hline 4 & & Gaetice depressus (De HaAN) & $6-25$ & c \\
\hline 5 & & Pachygrapsus crassipes RANDALL & $8-31$ & c \\
\hline 6 & & Nanosesarma gordoni (SHEN) & $1-6$ & $\mathrm{~d}$ \\
\hline 7 & Ocypodidae & Ocypode stimpsoni Ortmann & $16-26$ & $d$ \\
\hline 8 & & Scopimera globosa De HAAN & $5-10$ & d \\
\hline 9 & Xanthidae & Pilumnopeus indicus (DE MAN) & $4-8$ & $\mathrm{r}$ \\
\hline 10 & & Macromaedeus distinguendus DE HAAN & $8-19$ & c \\
\hline 11 & Pinnotheridae & Pinnotheres sinensis SHEN & $2-14$ & c \\
\hline 12 & Portunidae & Charybdis japonica (A. MiLne Edwards) & $23-124$ & c \\
\hline 13 & & Portunus pelagicus (Linnaeus) & $32-145$ & c \\
\hline 14 & Calappidae & Matuta lunaris (FoRSKAL) & $32-53$ & $\mathrm{r}$ \\
\hline 15 & Majidae & Hyastenus elongatus OrTmann & $25-32$ & $\mathrm{r}$ \\
\hline 16 & & $\begin{array}{l}\text { Pugettia quadridens } \\
\qquad \text { quadridens (DE HAAN) }\end{array}$ & $11-22$ & $\mathrm{r}$ \\
\hline
\end{tabular}

"d: dominant $(25 \leqq n)$; c: common $(10 \leqq n \leqq 24)$; $r$; rare $(1 \leqq n \leqq 9)$, where " $n$ " is the number of crabs collected during one survey.

1.

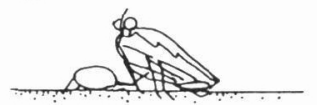

2.

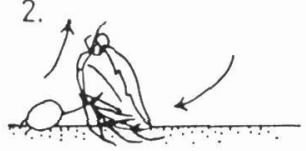

3.

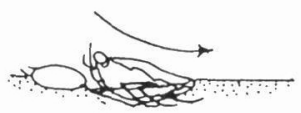

4.

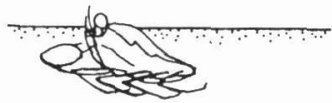

Fig.6 The manner of burial of E. japonicus in the sand (1.-3.) and its posture when burying its body most deeply in the sand (4.). rocks and burying in the sand. Crabs classified as staying on the rocks were those eating attached organisms or detritus, wandering, and copulating. Significant sexual difference were detected in the proportion of the active condition (wandering along the sand and staying on the rocks) and hiding condition (hiding under rocks and burying in the sand) in each period $\chi^{2}$-test, Sep. \& Oct., $\chi^{2}=73.2$, d.f. $=1, p<0.001$; Nov. $\&$ Dec., $\chi^{2}=61.6$, d.f. $=1, p<0.001 ;$ Jan. \& Feb., d.f. $=1, \chi^{2}=20.9, p<0.001$; Mar. \& Apr., $\chi^{2}=42.9$, d.f. $=1, p<0.001$; May and Jun., $\chi^{2}=18.6$, d.f. $=1, \quad p\langle 0.001)$. The males were mostly collected as they were wandering along the sand or staying on the rocks, whereas the females were collected hiding under the rocks.

\section{Attached organisms on E. japonicus}

Attached organisms were found on 93 crabs. They were green algae (Ulva pertusa, Enteromorpha sp. etc.), red algae (Porphyra tenerra, Gelidium sp. etc.), bryozoans, tubes of polychaetes (Serpulidae gen. sp.) and mussels 
Female

Sep.

\& Oct.

Nov.

\& Dec.

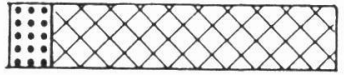

(15)

Jan.
\& Feb.

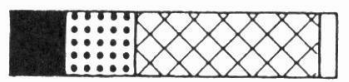

(18)

Mar.

\& Apr.

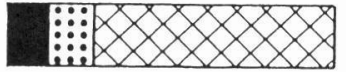

(15)

May

\& Jun.

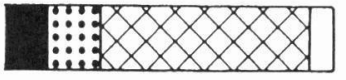

(48)
Male

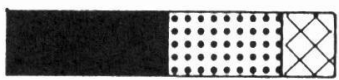

(31)

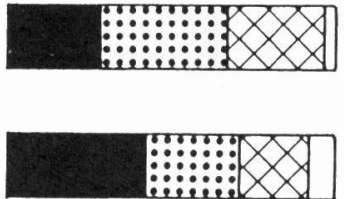

(28)

(38)

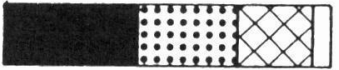

(37)

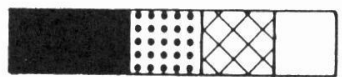

(37)

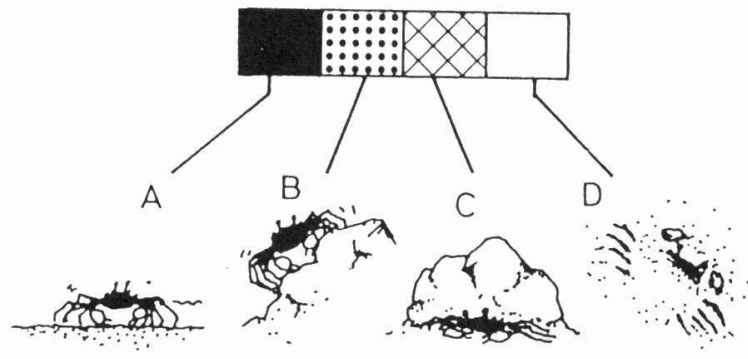

Fig.7 Posturing condition of E. japonicus at collection for each two-month period: A, wandering on sand; B, staying on rocks; C, hiding under rocks; D, burial in sand. Numbers in parentheses indicate total numbers of crabs collected.

(Mytilus edulis). All were common along the rocky shore in Tsuyazaki. Among these species, $U$. pertusa was the dominant one, being found on $95 \%$, as well as the largest alga on $90 \%$, of the crabs with attached organisms. The frequency distribution of 4 classes on the surface of the exoskeleton of E. japonicus over a 10-month period is shown in Fig.8. In both sexes, most crabs did not have attached organisms (classes 0 and 1) between September and December, but many had attached organisms (classes 2 and 3) between January and June. Class 3 (a large amount of attached organisms on the surface) appeared between March and June. Moreover, both in March and April and in May and June, the proportion of crabs with attached organisms (classes 2 and 3) was significantly larger in males than in females $\left(\chi^{2}\right.$-test, $\chi^{2}=6.95$, d.f. $=$ $2, p<0.05$ in Mar. \& Apr., and $\chi^{2}=12.82$, d.f. $=$ 2, $p<0.01$ in May \& Jun., respectively), but there was no significant difference between sexes in other periods $\left(\chi^{2}\right.$-test, $\chi^{2}=0.11$ in Sep. \& Oct., $\chi^{2}=0.37$ in Nov. \& Dec. and $\chi^{2}=1.83$ in Jan. \& Feb., all were d.f. $=1, p>0.05)$. 

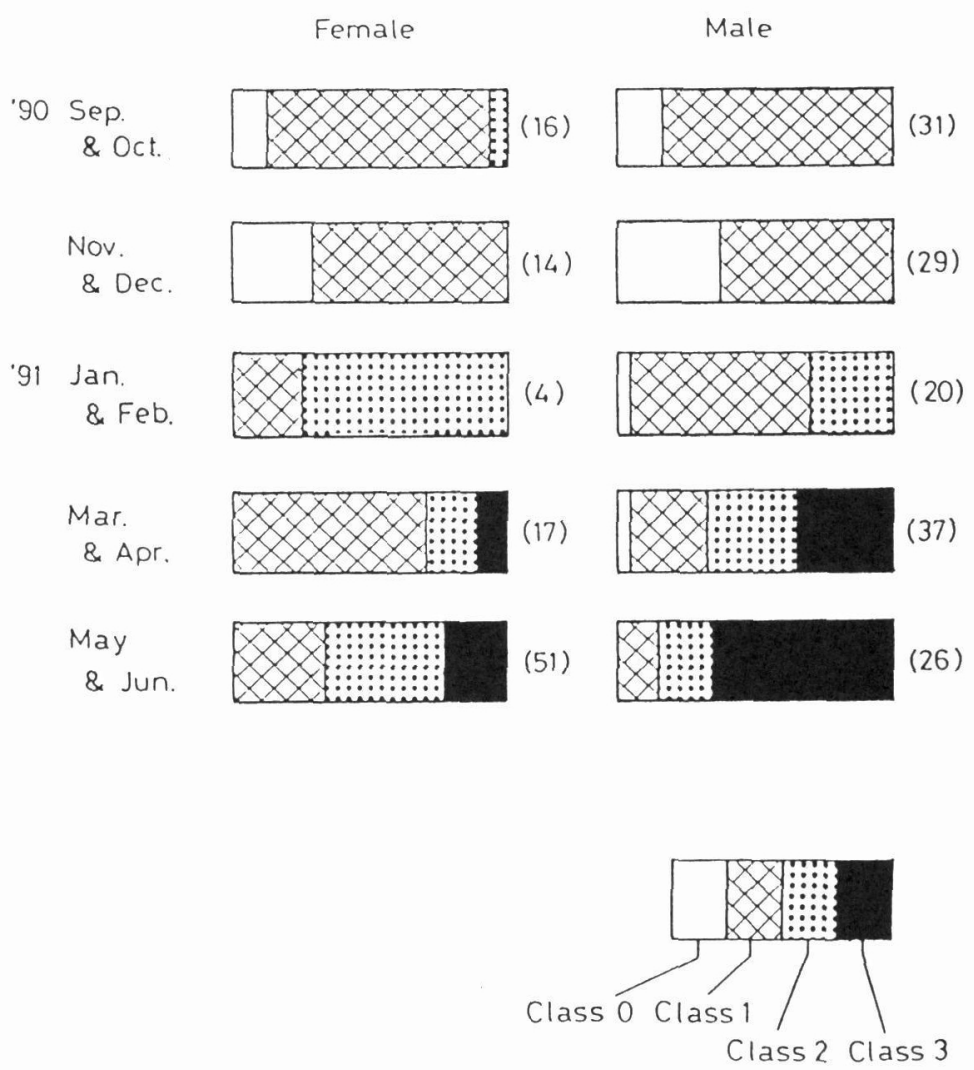

Fig.8 Coverage (class 0-4) of attached organisms on exoskeleton of E.japonicus. Numbers in parentheses indicate total number of crabs examined. For the details of class 0-4, see Fig.2.

\section{Discussion}

\section{Period of occurrence of $E$. japonicus and other brachyuran species}

Being collected from sandy shore with few stones, sandy shore with numerous stones and rocks as well as artificial rocky shore (Fig.5), E. japonicus is a crab occurring on various types of substrate. In addition, E. japonicus were collected almost throughout 10 months. Therefore, it is probable that they encounter many other brachyuran species in the inshore area. In case of the larger species, they were collected only in a limited period. Portunus trituberculatus, a migratory portunid crab in the Seto Inland Sea, is found mainly in the deeper water (20-30m depth) during the cold season and in the shallower water (less than $10 \mathrm{~m}$ ) during the warm season (Shiota \& Kitada 1992). Portunidae and calappidae crabs in Tsuyazaki may also migrate to the collection site before the warm season, and migrate to another region before the cold season. However, E. japonicus migrates from the river to the collection site before the cold season. It has been observed that many E. japonicus remained in shallow water were dead at the beginning of the warm season (KoBAyASHi \& MATSUURA, unpublished data). Therefore, the habitat of $E$. japonicus in inshore areas probably overlaps with that of other large 
species, especially C. japonica, but only for a short period. This means that E. japonicus spends its life in the sea during a season when other large crabs, which seem to utilize the same habitat, are absent.

\section{Behavior of E. japonicus}

Eriocheir japonicus has neither a fixed place of residence nor a burrow. Some crabs wander over the sand or rocks during the daytime, while others hide in the sand or under rocks. A closely related species, the Chinese mitten crab Eriocheir sinensis in Germany digs burrows $20-80 \mathrm{~cm}$ long in the intertidal zone (Peters \& Panning, 1933). E. sinensis resembles closely to $E$. japonicus in morphology. The difference between these two congeners is found in their mode of life of whether possessing a fixed place of residence.

Sexual difference in posturing conditions was detected at collection (Fig.7). The male crabs tend to wander or move more actively than the female crabs. The sexual difference in attached organisms (Fig.8) may reflect such a behavioral difference. Active crabs are more exposed. Consequently, the growth of algae attached to the active crabs are thought to be promoted. Accordingly, the fact that attached organisms were more frequently found on the males than the females would indicate higher activities of the males on the substrate during the daytime.

This behavioral difference is also attributable to the mating role. The mating of $E$. japonicus commences with the active behavior of the male which approaches and grasps the female without any marked precopulatory behavior. The male grasp the female and soon attempt copulation regardless of acceptance by the females (Kobayashi \& MatsuUra, unpublished data). Therefore, the male crab starts searching for the female crab during the daytime for increase in the opportunity of copulation.

Crabs with attached organisms (classes $2 \&$ 3 ) were caught mostly between January and
June (Fig.8). Kobayashi \& MatsuURa (1991) estimated that puberty moulting occurred in the freshwater area mainly in August and the migration into the sea occurred between September and December in Kagoshima. When 237 crabs were reared in aquaria containing seawater between September 1990 and July 1991 in Tsuyazaki, no moulting was observed (Kobayashi \& MatsuUra, unpublished data). Class 0 (clear surface) is thought to comprise the newly-moulted crabs. The appearance of this class mainly between September and December indicates that recently-moulted crabs are in the sea during this period. These crabs seem to have migrated downstream from the freshwater area during these months. Since the appearance of class 3 (a large amount of attached organisms on the surface of the exoskeleton) was limited to the period of March to June, it is suggested that the crabs reaching the sea between September and December stay till June without moulting, and the attached organisms grow larger on the exoskeleton during this period.

\section{Acknowledgements}

We wish to thank the staffs of the Marine Biological Laboratory and Fisheries Research Laboratory, Kyushu University, for their kind assistance. This study was partly supported by a research grant from the Research Institute of Marine Invertebrates, which is gratefully acknowledged.

\section{References}

Kikuchi, T., M. Tanaka, S. Nojima and T. TAKAHASHI, 1981. Ecological studies on the pebble crab, Gaetice depressus (de Haan). I. Ecological distribution of the crab and environmental conditions. Publ. Amakusa Mar. Biol. Lab., 6: 23-34.

Kobayashi, S. and S. Matsuura, 1991. Longitudinal distribution of the Japanese mitten crab in the Kaminokawa River, 
Kagoshima. Nippon Suisan Gakkaishi, 57: 1029-1034. (In Japanese with English summary).

Morita, T., 1974. On mating behavior of Eriocheir japonica DE HAAN. Res. Crust., 6: 31-46. (In Japanese with English summary). NAKASONE, Y., 1977. Crab zonation in the Yuhi River, Okinawa Island. Jpn. J. Ecol., 27: 6170.

Peters, N. und A. Panning, 1933. Die chinesische Wollhandkrabbe (Eriocheir sinensis H. MiLNe-Edwards) in Deutschland. Zool. Anz., 104: 1-180. (In German).

Shiota, K. and S. Kitada, 1992. Life hisory of swimming crab in Hiuchi Nada, Seto Inland Sea estimated from marking experiments. Nippon Suisan Gakkaishi, 58: 2297-2302. (In Japanese with English summary).

TAKAhashi, K., T. Miyamoto, Y. Mizutori and M. ITO, 1985. Ecological studies on rocky-shore crabs in Oshoro Bay. Sci. Rep. Hokkaido Fish. Stn., 27: 71-89. (In Japanese with English summary).

W ADA, K., 1976. The distribution of three species of ocypodid crabs in the estuary of Waka River, mainly examined in relation to the granularity of substratum. Physiol. Ecol. Japan, 17: 321-326. (In Japanese with English summary).

\section{SATOSHI KOBAYASHI}

Department of Fisheries, Faculty of Agriculture, Kyushu University,

Hakozaki, Higashi-ku, Fukuoka 812, Japan
小林哲・松浦修平 モクズガニ Eriocheir japonicus DE HAAN の海域における出現状況と行動

モクズガニEriocheir japonicus の海域での生息 環境と出現時期, 及び行動を記載した. 福岡県宗像郡 津屋崎町海岸の潮間帯から浅海域において, 1990年か ら1991年にかけての 1 年間, ほぼ $2-3$ 日に 1 度の割 合で, 日中の干潮時に 1 時間, 手網による採集を行っ た. モクズガニは 9 月初旬から 7 月初旬 (初秋から初 夏)にかけて, 岩礁域, 転石の混じる砂浜, 砂浜のい ずれにおいてあ採集され，底質にとらわれずに移動し ていることが明らかになった. 各生息場所では他の力 二類も同様に採集されたが，モクズガニは潮間帯では 比較的大型のカ二であり, モクズガニが海域へ侵入す ることによる群集への影響も考えられた．そこで各生 息場所における出現時期を他の力二類と比較すると, 年中出現するイソガニなどの小型種とは重なっていた が,イシガニなどの大型種との重なりは小さく，他の 大型種の出現が初夏から晚秋にかけてであるのと逆転 していた。このようにモクズガニは，主に生息場所利 用において最も類似していると思われる大型力二類が まれな時期に，海域で過ごすことが明らかになった。 また，モクズガニは特定の巣穴を造らずに潜砂するか 岩の下に身を隠していた. 移動（放浪）および摄慨は 水中で行われ, 干出時には隠れてほとんど活動が見ら れなかった. 多くの雌が岩の下に隠れた状態で採集さ れたのに対し，雄では放浪個体が多く採集され，雄が 雌に比べ活動性の高いことが推察された。 また体表の 付着生物（主に緑藻類）が䊒よりあ雄により多く見出 された.このことは付着藻類の成長に必要な太陽光下 で過ごす時間の違いを示しており，雄の活動性の高さ を反映していると考えられた。 